\title{
A PRELIMINARY EXPLORATION OF OPERATING MODELS OF SECOND CYCLE/RESEARCH LED OPEN EDUCATION INVOLVING INDUSTRY COLLABORATION
}

\author{
UlfOlsson [ulf.olsson@su.se],Stockholm University, SE-106 91 Stockholm, Sweden [bttp:/ / wmw.su.se]
}

\begin{abstract}
Scientists from five Swedish universities were interviewed about open second cycle education. Research groups and scientists collaborate closely with industry, and the selection of scientists for the study was made in relation to an interest in developing technology-enhanced open education, indicated by applications for funding from the Knowledge Foundation 2013. The study is founded on Conole's (2012) seven organizational purposes for open education, Coursera's eight models (Daniel, 2012), and Clarke's (2013) four strategies for open education, and raises the question whether open education and MOOCs might be a way to reinforce research collaborations and research environments. The researchers displayed a positive attitude towards expanding the technology-enhanced learning and openness, and foresee few problems with openness when industry participates in teaching. Nonetheless, the scientists' operating models and strategies for developing technology-enhanced learning and open education, are vague. Conclusively: although the interest is obvious, in order to succeed with technology-enhanced open education and strengthening the research groups, the variables for purposes, operating models, strategies, pedagogic models, and obstacles need to be calibrated and made more deliberated, preferably in collaboration between the scientists and industry.
\end{abstract}

Keywords: Operating models, ICT, Open Education, Higher Education, MOOCs, Industry collaboration

\section{Introduction}

Is second cycle education in e.g. the form of MOOCs (Massive Open Online Courses) feasible for scientists and companies to develop and implement collaboratively? Can education be established with a democratic approach, accessible to anyone, and flexible in terms of time, space, peer processes, and web-based tests, compatible with research- and education collaborations between academia and industry? Do research groups and industry representatives discern advantages in open education, or do they foresee problems in making the latest research results and company data public? Do the research groups have any purposeful, organizational objectives, operating models, and strategies for the development of technology-enhanced open education? Which pedagogic challenges and obstacles are they facing? These issues comprise the starting point of the present study. 


\section{Background}

Within higher education and research, collaboration between universities is increasing in order to create platforms for marketing and conducting MOOCs (open, flexible online courses, harbouring many participants) (Daniel, 2012). These courses are believed to provide a great opportunity for more people to acquire access to higher education, and to develop new models for education, although no novel forms of the education have as yet been pinpointed. "The motivation for some MOOCs is a philanthropic one and for others a business proposition. However, in both cases, there is the challenge of finding a viable model that allows for sustainability of MOOC provision." (Yuan \& Powell, 2013, pp.3-4). A common preconception among researchers and debaters is that MOOCs are changing the preconditions of the universities' operations. Other researchers and debaters are more apprehensive (Karsenti, 2013). Publishing in open access journals is a current parallel development (Carroll, 2013). Research results are thus made available outside the journals of commercial publishing houses, increasing the access to research results for people outside academia. Open education and open publishing are part of a change that has been ongoing for decades, and include the concepts of open source and open content as well. Even though many teachers in academia view MOOCs and IT within teaching with scepticism, new commercial stakeholders exist today, who may influence the operating models (Bokor, 2013; Karsenti, 2013). Commercial actors have in certain cases made large investments in order to build infrastructure and develop business models.

Today's development of flexible and open courses may be compared with the development during the 1990s, when many smaller universities developed distance education, with the purpose of extending and broadening their student recruitment. As a consequence of these efforts, pedagogy improved and so did individual teachers' competence in using IT-tools in their teaching. The universities also invested in technical infrastructure to sustain distance education. A relevant question concerns which education and research environments that were strengthened by this development. Possibly, those subjects, whose efforts within distance education were increased, were fortified in comparison with other subjects at the university. It might be discussed, however, whether the subject itself or research in the field thereby acquired increased opportunities to become prioritized at the university. We may assume that the international impact of the research environments was not notably affected.

It is not self-evident that the strongest research environments were the ones investing in distance education or web-based education. It might rather have been subjects and environments "forced" to increase their student numbers in order to enable them to carry out planned education. It was often individual teachers and institutes that developed the new forms (Norton et al., 2013). Furthermore, the teaching was often developed, as well as conducted by, non-doctorate teachers (Norton et al., ibid.). David Bull (2012) mentions this in connection with the current development of open online courses, MOOCs: "Elite universities who have built their reputations on research outputs are not necessarily the leading lights in online pedagogy, this strength is probably vested in lesser known institutes who have a long history of distance education provision or well established e-learning profiles." The "elite universities" that were early in creating MOOCs have rather achieved their reputation through their research - not their teaching (Daniel, 2012).

Daniel (2012) criticizes the hype that MOOCs have given rise to, but can see advantages if it leads to institutes developing and refining their operations. Developing technology-enhanced and Internet-based courses is not a task for an individual professor or teacher, but is rather a team effort requiring a variety of competences (Daniel, 2012). Rubin (2013) argues that conducting efficient and qualitative teaching requires substantial input. These opinions are contrary to the frequently repeated standpoints of education politics, stating that education and research are 
closely linked, and should be executed by the same individuals. Scientific support for these standpoints is however hard to find (Hattie \& Marsh, 2004).

Few people believe that MOOCs will change all higher education, but the development in terms of increased number of open courses might be an example of an evolution where information technology exerts a larger impact than previously, acting on the university organizations and operating models as well (Clarke 2013; Norton et al., 2013; Kelly \& Hess, 2013). The new technique is often utilized to digitalize old teaching models, and to facilitate more flexible study forms. Technology enhancement of educational processes and competence development has however not attained similar significance, in spite of being offered by many disciplines (Broman \& Östholm, 1997; Chesler et al., 2013). Will perhaps pedagogic models for Internet-based learning in coalition with research now gain a greater influence on the universities' operations, and be utilized on a larger scale than previously?

The pedagogic approach of MOOCs primarily concerns differences between courses with a large-scale thinking perspective, to a large degree comprising automatically managed processes, and courses where participants actively take part in and affect the realization of the course (Siemens, 2012a; Siemens, 2012b; Rodriguez, 2013). 'xMOOCs' are often used to describe courses of the first type, and 'cMOOCs' to describe the second type (Hill, 2012). George Siemens, one of the pioneers in the area, describes the differences, using as starting point his own cMOOC model:

"Our MOOC model emphasizes creation, creativity, autonomy, and social networked learning. The Coursera model emphasizes a more traditional learning approach through video presentations and short quizzes and testing. Put in another way, cMOOCs focus on knowledge creation and generation, whereas $x M O O C$ focus on knowledge duplication. I've spoken with learners from different parts of the world that find $x M O O C$ extremely beneficial as they don't have access to learning materials of that quality at their institutes." (Siemens, 2012a)

Even though dichotomization of the pedagogic approaches runs the risk of being a dubious simplification and thus should be avoided, the pedagogic approach is of great importance and interest to the present study, since it focuses on research collaboration and second cycle education, and what this entails in terms of demands on creative and independent educational processes. Apart from the course content, the number of students differs significantly between first cycle and second cycle education.

The conditions for choosing an operating model differ between state-run and private universities, and different research groups and companies may act independently within their model in order to strengthen their networks and their status as research environment. In their report University of the Future, Ernst and Young (Bokor, 2013) suggest a number of alternative models for the Australian universities, one of which emphasizes the smaller universities' possible direction:

"Smaller universities will become increasingly focused on a narrow range of research programs. To make this work, they will need to explicitly tie education programs and industry partnerships to these focused programs - as per the 'Niche Dominator' model - or invest in a distinct student experience for teaching and learning programs not tied to research.” (p.22) 
The present study explores whether individual scientists and research environments are aware of these orientations and possible purposes. Conole (2012) summarizes the organizational purposes of open education in seven categories:

- Enhancing the institute's reputation

- Extending the university's reach to new users and communities

- Recruitment of students from those who use open educational resources repositories

- Supporting widening participation

- Providing an experimental base of material for use within the university

- Accelerating uptake and use of new technologies

- Acting as a catalyst for less formal collaborations and partnerships (p.209)

We may assume that some of Conole's organizational purposes are particularly relevant to research groups collaborating with industry in research projects and in matters of education. The present study investigates whether the interviewed scientists find operating models interesting, or whether their own research group views them as being associated with one or more of Conole's purposes.

Eight possible models are listed in Coursera's partner contract with the included universities:

- Certification (students pay for a badge or certificate)

- Secure assessments (students pay to have their examinations invigilated (proctored))

- Employee recruitment (companies pay for access to student performance records)

- Applicant screening (employers/universities pay for access to records to screen applicants)

- Human tutoring or assignment marking (for which students pay)

- Selling the MOOC platform to enterprises to use in their own training courses

- Sponsorships (3rd party sponsors of courses)

- Tuition fees

(Daniel, 2012, p.7)

In the present analysis, Coursera's list over models was employed in conjunction with four different strategies for open education that universities may select:

- Launch their own MOOC

- Join an existing MOOC-consortium

- Develop courses to fulfil the criteria for MOOCs

- Emphasize the quality of personal development and of meetings in campus environment

(Clarke, 2013)

The organizational purposes, models and strategies above are not selected to define the boundaries of open education or the most important topics as such in open education. They constituted the basis for the interviews in the present study and are chosen to give different scopes, from organizational purposes, through more or less defined models, to practical strategies. 


\section{Procedure}

A total of 11 scientists from five research environments at five Swedish universities were interviewed. The research environments were approached and selected on the basis of their application for funding from the Knowledge Foundation within the announcement for "IT in Higher Education" 2013. As the applications concerned open educational resources and information technology, the selection ensured that issues about open education, employing IT within education, research, and industry collaborations were not novel to the interviewed scientists. This approach allowed us to assume that the interviewed scientists had pondered over these issues somewhat more than other scientists in similar environments. The five research environments are situated at comparably small universities in Sweden, and have established collaborations with industry, Table 1.

Table 1: The researchers interviewed come from five research groups.

\begin{tabular}{|c|c|c|c|c|}
\hline $\mathrm{H}$ & $\mathbf{J}$ & $\mathrm{K}$ & $M$ & $\mathbf{V}$ \\
\hline $\begin{array}{l}\text { Centre for Applied } \\
\text { Intelligent Systems, } \\
\text { CAISR, Halmstad } \\
\text { University, focuses on } \\
\text { "aware" intelligent } \\
\text { systems: human aware, } \\
\text { situation aware, and } \\
\text { self-aware. The centre } \\
\text { builds around research } \\
\text { groups in three scientific } \\
\text { areas: Signal Analysis, } \\
\text { Mechatronics and } \\
\text { Machine Learning. } \\
\text { Intelligent systems built } \\
\text { for the imminent } \\
\text { "ubiquitous future:" } \\
\text { with data, sensors and } \\
\text { embedded computers } \\
\text { present everywhere. } \\
\text { Approximately } 25 \% \\
\text { education and } 75 \% \\
\text { research. }\end{array}$ & $\begin{array}{l}\text { The research group } \\
\text { Materials \& } \\
\text { Manufacturing, School of } \\
\text { Engineering, Jönköping } \\
\text { University, has two main } \\
\text { research direction, } \\
\text { Surface technology and } \\
\text { Metals Casting. The key } \\
\text { focus of both directions } \\
\text { is the relation between } \\
\text { the process, material } \\
\text { microstructure and the } \\
\text { resulting physical and } \\
\text { mechanical properties of } \\
\text { the bulk material or } \\
\text { surface material of a } \\
\text { finished component. The } \\
\text { metals casting activity is } \\
\text { the largest and focus } \\
\text { primarily on cast } \\
\text { magnesium-, aluminium } \\
\text { alloys and cast iron. } \\
\text { Approximately } 10 \% \\
\text { education and } 90 \% \\
\text { research. }\end{array}$ & $\begin{array}{l}\text { CTF at Karlstad } \\
\text { University, is an } \\
\text { interdisciplinary } \\
\text { research center } \\
\text { focusing on service } \\
\text { management and } \\
\text { value creation } \\
\text { through service. } \\
\text { Three multi- } \\
\text { disciplinary research } \\
\text { themes: } \\
\text { Service organizations } \\
\text { and Employment } \\
\text { relations, which deals } \\
\text { with new } \\
\text { organizational } \\
\text { models, Service } \\
\text { innovation, based on } \\
\text { a user involvement } \\
\text { approach and } \\
\text { Customer } \\
\text { experiences, strongly } \\
\text { anchored in the VINN } \\
\text { Excellence Center } \\
\text { SAMOT. } \\
\text { Approximately } 20 \% \\
\text { education and } 80 \% \\
\text { research. }\end{array}$ & $\begin{array}{l}\text { The research center } \\
\text { Sensible Things that } \\
\text { Communicate, STC, Mid } \\
\text { Sweden University, offer } \\
\text { an education in the } \\
\text { subjects of Electronics } \\
\text { as well as Computer } \\
\text { Engineering. The group } \\
\text { builds around research } \\
\text { in electronics, focus on } \\
\text { Sensor Technologies and } \\
\text { Sensor Systems. The } \\
\text { research is targeting } \\
\text { both technology and } \\
\text { design issues, } \\
\text { integrating functionality } \\
\text { and technology research } \\
\text { with a focus on wireless } \\
\text { sensor solutions and } \\
\text { ambient intelligence. } \\
\text { Approximately } 25 \% \\
\text { education and } 75 \% \\
\text { research. }\end{array}$ & $\begin{array}{l}\text { The research group at } \\
\text { PTW (Production } \\
\text { Technology West) } \\
\text { belongs to University } \\
\text { West. It is also a part of } \\
\text { PTC (Production } \\
\text { Technology Centre), } \\
\text { which run in partnership } \\
\text { with University West, } \\
\text { Innovatum Technology } \\
\text { Park, and the } \\
\text { manufacturing industry } \\
\text { in the region. The } \\
\text { research is focused on } \\
\text { development on } \\
\text { manufacturing } \\
\text { processes in the } \\
\text { manufacturing industry, } \\
\text { and more specifically on } \\
\text { (i) flexible automation } \\
\text { and robotics, (ii) surface } \\
\text { coating processes } \\
\text { (Thermal spraying), (iii) } \\
\text { welding, and (iv) cutting } \\
\text { processes. } \\
\text { Approximately 30\% } \\
\text { education and } 70 \% \\
\text { research. }\end{array}$ \\
\hline $\begin{array}{l}\text { Approximately } 30 \\
\text { people employed within } \\
\text { CAISR, out of which } 15 \\
\text { have PhDs and } 3 \text { are } \\
\text { professors. Currently } 8 \\
\text { PhD students, and right } \\
\text { now in the process of } \\
\text { hiring three more. }\end{array}$ & $\begin{array}{l}\text { As a total the group are } \\
32 \text { persons working full } \\
\text { or part time. They are } \\
\text { also working intimately } \\
\text { with other research } \\
\text { groups both at JTH and in } \\
\text { Luleå adding to two } \\
\text { more persons. }\end{array}$ & $\begin{array}{l}\text { The center has about } \\
30 \text { PhDs and } 25 \\
\text { doctoral students } \\
\text { who are variously } \\
\text { involved in business } \\
\text { administration, } \\
\text { working life science, } \\
\text { sociology, psychology } \\
\text { and sociology of } \\
\text { religion. }\end{array}$ & $\begin{array}{l}\text { The research group has } \\
\text { about } 50 \text { people, out of } \\
\text { which } 25 \text { have PhDs and } \\
25 \text { are PhD students. }\end{array}$ & $\begin{array}{l}\text { The size of the research } \\
\text { group is about } 60 \\
\text { people divided between } \\
\text { senior research staff } \\
\text { (28), PhD students (21), } \\
\text { Research engineers and } \\
\text { administrative staff. }\end{array}$ \\
\hline
\end{tabular}




\begin{tabular}{|c|c|c|c|c|}
\hline $\begin{array}{l}\text { The main focus of } \\
\text { majority of research } \\
\text { being done within } \\
\text { CAISR is collaboration } \\
\text { with industry, both local } \\
\text { and global companies. }\end{array}$ & $\begin{array}{l}\text { Long running } \\
\text { collaborations nationally } \\
\text { with Swerea } \\
\text { SWECAST under the } \\
\text { casting Innovation } \\
\text { Centre flag with } 15 \\
\text { companies involved. } \\
\text { Many other } \\
\text { collaborations on } \\
\text { national and } \\
\text { international level. }\end{array}$ & $\begin{array}{l}\text { CTF develops and } \\
\text { conducts research } \\
\text { projects in close } \\
\text { collaboration with } \\
\text { business and public } \\
\text { organizations both on } \\
\text { national and } \\
\text { international level. }\end{array}$ & $\begin{array}{l}\text { A lot of collaboration in } \\
\text { both research and } \\
\text { teaching. The research in } \\
\text { close cooperation with } \\
\text { industrial partners. } \\
\text { Collaboration in three } \\
\text { educational programmes } \\
\text { with other institutions. } 50 \\
\text { industry partners during } \\
\text { last } 5 \text { years. }\end{array}$ & $\begin{array}{l}\text { The research group has } \\
\text { a well-established } \\
\text { network and cooperate } \\
\text { in a multifaceted ways } \\
\text { with industry, academy } \\
\text { and research institutes, } \\
\text { on a regional, national } \\
\text { and international level. }\end{array}$ \\
\hline $\begin{array}{l}\text { Undergraduate, } \\
\text { graduate and post } \\
\text { graduate teaching. All } \\
\text { currently done on } \\
\text { campus, and do not } \\
\text { offer any distance } \\
\text { courses. They are doing } \\
\text { commissioned } \\
\text { education from time to } \\
\text { time. }\end{array}$ & $\begin{array}{l}\text { Undergraduate, } \\
\text { graduate and post } \\
\text { graduate teaching. } \\
\text { Further just below 1\% of } \\
\text { the activity is industry } \\
\text { courses based on } \\
\text { revenue. No distance } \\
\text { education. }\end{array}$ & $\begin{array}{l}\text { Undergraduate, } \\
\text { graduate and post } \\
\text { graduate programs } \\
\text { and courses all taught } \\
\text { on campus. Neither } \\
\text { distance nor } \\
\text { commissioned } \\
\text { education is } \\
\text { undertaken. }\end{array}$ & $\begin{array}{l}\text { Undergraduate, graduate } \\
\text { and post graduate } \\
\text { teaching. Two programs } \\
\text { at distance, two on } \\
\text { campus, one blended } \\
\text { master. }\end{array}$ & $\begin{array}{l}\text { Education on } \\
\text { undergraduate and } \\
\text { post graduate level, } \\
\text { including master and } \\
\text { PhD level. Concept for } \\
\text { collaborative education } \\
\text { and training of } \\
\text { engineers on Bachelor } \\
\text { level together with } \\
\text { industry. }\end{array}$ \\
\hline
\end{tabular}

In common for all five research environments are:

- Located in comparatively small cities, with the ensuing difficulties in getting professionals to apply for campus education on a regular basis.

- Interest in research collaboration with industry.

- Industrial $\mathrm{PhD}$ students as one form of collaboration with industry.

- Awareness of industry's needs for training that can be combined with daily tasks at the work place.

There are of course differences in the research volume, in the number of students and in how comprehensive the collaboration with industry and other institutions is.

Each project leader participated in an interview, along with a varying number of colleagues in their research groups. The semi-structured interviews, conducted 30 May - 2 July 2013 at each respective university, were recorded, transcribed, and subsequently analysed. The interviews were carried out for on average $1 \mathrm{~h} 30$ minutes. The respondents were informed that they would not be quoted by name and any discussed collaboration would not be identified. The unit for the interview was the research environment. The researchers were encouraged to give their own opinions upon the questions, independently of the university's strategy and policy documents.

The researchers were asked, based on an interview-guide, about organizational purposes, operating models and strategies for open education. These topics were followed up by questions concerning openness and industrial collaboration and also pedagogical challenges and obstacles. The interviews were conducted in Swedish with J, K, M, V, and in English with H. The citations are accordingly translated to English (except for $\mathrm{H}$ ).

The statements were analysed and categorized under more general umbrella headings to produce a description of points made with reference to their nature and frequency. Particular quotations were selected to represent statements in the findings. The purpose was to obtain more in-depth knowledge about the different ways the researchers think. Quantitative or statistical analysis was not the purpose of the study. 


\section{Results}

\section{Organizational purposes}

The organizational purposes of open education, as suggested by the scientists, can be divided into two different categories. One category is primarily about demonstrating the institutional operations. Although some scientists claim that all universities hold a large potential for strengthening their brand whether they are well-known or not, the researchers emphasize the potential of separate research groups for making themselves more known, increasing their status. There are examples of very respected research groups at otherwise rather unknown universities. "I see it as a tremendous opportunity; to bave one or two MOOCs within a specific area that we also would make international, would be immensely propitious." (K1) The open education becomes a marketing tool, a "showcase", allowing the research group to display their research and education. Other scientists will be able to see what (prospering) projects are being run; collaboration would be facilitated, and perhaps even scientists recruited. "It is really about how to acquire status in the world." (J1) "As world-leading, you want renown." (J1).

The second category entails that presumptive students may be enticed into applying the offered education, but the scientists' discussions diverge about the choices students make. One viewpoint stated that students as well as employers link particularly Engineering Education with the status of the university. Hence, we may assume that open education might reinforce the brand of a university, but the status of a course and of a university is a complex matter. High application pressure, along with other factors, affects the status. Some doubts were raised in this context, e.g. about open education not being examined in a normal procedure, only yielding a course certificate when the student is approved. Will the university itself consider this equivalent to other courses? Does the status of an open course correlate with the status of the university? A followon question lifted by the scientists concerned how employers assess a certificate from an open course. Several research groups remarked that we harbour a picture of students choosing from a status perspective, but when asking them, this is not the case. Students from China were provided as examples: "What do you mean difference, it is Sweden." (V2) The students did not evaluate the universities from an age perspective, but considered other aspects. Students do not generally reason like teachers about age and status of the universities. Many factors influence the students' choices. The university being situated in or nearby their domicile is a strong factor, but the reputation of e.g. a good party life during weekends is significant for the choice.

Since the courses offered by the interviewed researchers often are very niched, it is hard to recruit sufficient number of course participants, and hence to offer the course at all, even with local participants. "So, it is really hard to design a course and make sure that there are enough people there" (H2). Not all students are attracted by the prospect of travelling to relatively small towns where the research groups' universities are located, to participate in studies. "Coming from Gothenburg to study here is not going to happen." (H1) It is particularly difficult to attract working persons from other parts of the country on a regular basis. Flexible forms of work are more suitable, and may even result in the companies saving on in-service training of personnel. "In this new project, IT for higher education, the approach is to have one part open to learn for all. Then you are coming to an assessment part. One has to find a transition, but all study material should be open. It becomes a showcase for those who want to window-shop a bit. You can see what we are doing well. What the course is about so, if you just want to improve yourself it is free for further training." (M1) The flexibility may consist of completely open courses, which, according to the scientists, is encouraged by several large companies, since these may be a cost-effective alternative to training in the companies' own regime. 
The desired increase in student recruitment mentioned, predominantly concerned second cycle education. In one interview, the recruitment source in Sweden being insufficient was professed as the primary reason for opening up the education. The prospect of attracting more and better students to the courses by creating a larger interest in the research and education areas was declared. However, not all research groups concurred with that, even though extended flexibility within master education would facilitate participation by foreign students. Course collaboration among the universities is an option, even if it can be complicated to arrange but "As long as no one exploits someone else it can usually be managed in some way or other." (V2)

The interviewed scientists believed that augmentation of the status would be a strong motive for investing in open education and openly published education resources. Building a brand was however deemed as problematic. The researchers mean that having a high status from the start, like MIT with its several affiliates, facilitates further development of the brand. You need to be famous from the start in order to acquire higher status. A small, unknown university does not posses comparable preconditions. Being part of an organization, marketing education from different universities, was one option mentioned.

Conole's (2012) organizational purposes, to develop reusable course materials, or contributing to the university utilizing IT, were not emphasized by the interviewees. Open education functioning as a catalyst for development of less formal networks and collaborations was broached in connection with the view that open education might be a means to tie additional external contacts to the research environment. Several scientists mentioned the possibility of making courses more accessible and the research group more public, by extending the use of social media. Each scientist should be more active in order to increase the knowledge about the group's research, and about education options.

\section{Operating models}

If demand for increased flexibility and accessibility is an indisputable assumption, with its challenges and obstacles, then the question whether the education should be open or not is more complex. The incentives to develop and conduct open education are not equally debated in the different research groups, but the following questions recur frequently: Why should we change something that is functioning? We reach the peak rate (maximal number of students paid for by the government), and are not paid for the extra work. "Why should we offer a course for thousands of students when we are not paid for what we do?" (K1). The discussion about open education is new, and the groups indicate that many ambiguities exist in terms of the purposes, and many choices of path remain.

The research groups were doubtful about the possibilities of making a profit from open courses in second cycle education. Their courses are usually highly niched; recruiting the number of students required for generating sufficient profits would be problematic. "It must be so unique that it cannot be found at any of the big dragons in the U.S. if I may say so. It must be incredibly niched, if one will get a group who might be interested in it." (M2) On the other hand, a sufficiently niched education might facilitate charging fees. The link to commissioned education, and various types of upgrading courses, is obvious. A plausible payment model - apart from students paying for a highly niched course - would be to provide texts, audio, and videos, etc. for free, while charging for the interactive part, the direct contact with the teacher, the scientist, or the supervisor. Universities and companies developing examinations and validations in collaboration might be a way to find new forms of education. One researcher suggested linking mobile phone apps with courses, allowing the course organizers to charge for their downloading. In the end, the open courses might generate something of interest, but they considered profit possibilities low, as well as the 
incentives. The operating models described by the interviewees were not adequately reasoned, with a clear purpose and long-sightedness.

\section{Strategies for open education}

Making campus courses more flexible is a development positively viewed by the researchers, as they are aware of the aspirations of the companies. Increased flexibility and possible individual adaptation are ambitions held by the different research groups. It promotes collaboration with companies as well as student recruitment. Furthermore, there is an underlying, more or less implicit stipulation that university education utilizes information technology, modern pedagogy, and is made more accessible, which is not questioned by the scientists. Notwithstanding, research groups and individual scientists display moderate activity in terms of handling these demands.

One researcher expressed an idea about affiliating to an existing MOOC-consortium, which is one of the ways pointed out by Clarke (2013) as a possible strategy for universities that want to develop their education. This would make research groups from non-state universities visible and raise their status, attracting new contacts.

Yet another way, mentioned by Clarke (2013), is to launch your own MOOC. One of the research groups nurtures well-advanced plans to publish open educational resources on their own site, but the operating model is still indefinite. An obvious step is to introduce fees in connection with examination (see above; Daniel, 2012).

The researchers regard publishing as a means to develop their own range of courses until the criteria for MOOCs are met (Clarke's third way [2013]); the most feasible course materials mentioned in this context were various recorded features and lecture notes. A gradual augmentation of the open part of existing education was deemed possible to carry out, although lack of time and money was voiced. Since no structures were to be altered, and (tacitly) no teacher would be forced to publish material without consent, no conflicts with individual, judicial, or administrative systems were expected. Present course structures, feedback, and examination forms would be preserved. Laboratory work requiring a special environment would not be a problem, and increased control and validation were not expected. "It is novel terrain now, bub. It is quite a big challenge to go from the one extreme to the other." (V1)

Clarke's (2013) fourth way points to profiling the quality by personal development and meetings in campus environment. Compared to the other strategies, this approach is not as timeconsuming or costly. This path is preferred by some of the research groups that wish to maintain their structure as well as current funding, under the implicit condition that collaborating companies and future students also prefer this type of education. It is a well-known form, and holds a potential for improvement.

\section{Openness and industrial collaboration}

The research groups collaborate closely with industry, particularly in terms of research, but also in educational matters. Common interesting research areas are identified; and collaborations within education take place, identifying competences, besides finding projects and data for project work and theses. The doctoral students carry out a great deal of their work at companies. In many cases their project concerns new processes, services, and products, not self-evidently viewed as publicly accessible. The scientists did not consider the openness that open education entails a big problem for their collaboration with industry. There is no difference between campus courses and open courses in terms of what is allowed to be published. Confidential data in campus 
courses are confidential in open courses as well. Student theses are processed as previously, even though the procedure differs slightly between the research groups; but the routines are maintained. A distinction is often made between pure factual results, retained by the company, and publicly judged theses that comprise theory, methods, work procedures, and discussion. In some cases, standardized and anonymous data may be utilized, but in certain specific studies problems may arise. Retrieving information about which data that may be used is particularly problematic when companies owned by larger international corporations are involved. The process is simpler when dealing with smaller companies. "In smaller companies, one person rules." (V1)

General and comprehensive courses and work involving generic problems are easier to run openly. However, problems arise when education entails "know how", how to do things, since economic, competitive advantages might be involved. The research groups differ in their view on whether this problem is brought to attention or not. One group points out that certain companies wish to keep their contacts and educational efforts concealed, while others convey that companies are only marketing themselves in the educational collaboration. When concealment is requested it most likely concerns new investments, new areas where the companies are planning to extend their commitments. One researcher gave also an example of security-classified companies. "We work with security-classified companies even what they know is secret." (V1) When no problems with industrial collaboration are discerned, it is perceived that the companies are in control and know what information to make public. Companies' participation may be compared to guest lectures, where they reveal what they know and display what they are proud of, a marketing strategy for the companies.

The rights to research results in research collaborations are regulated by agreements, but these are not completely unproblematic since research often is financed by public funds. In certain cases the university is the part inviting for collaboration, stipulating the conditions, but in other cases of collaboration, the rights agreements allow the companies to specify what should be made public. "So, as a taxpayer, I think perhaps I would prefer it to be more open than now, and maybe less company sometimes, buh." (V1)

\section{Pedagogic challenges}

When the research groups discussed open education, they incorporated methods for making courses more flexible and accessible with the aid of information technology. Several groups expressed a strong wish to make their education environment more flexible, in spite of not knowing whether that involved different solutions for the present campus students and for industry collaboration. A common starting point was however that more course material would be produced and made publicly accessible. Most importantly, material not publicly accessible in learning management systems (LMS) was to be published openly, and more lectures were to be recorded and made accessible. Course material and modules were to be made shorter, facilitating their use in other contexts.

Accessibility of the course material on the Internet would first and foremost facilitate studies by working people, who cannot be physically present at the university, and who need to study at times and at a speed on their own terms. The division into shorter modules further aids these individuals, and also others who wish to combine studies more freely than is possible today. "It is simply a trend in society to make information and knowledge accessible; that it fits into the work procedure, with many different projects during a working day and a week, to be able to individualize the course, making it accessible in accordance with individual needs." (H1) Other universities' open educational resources should also be utilized. The purpose is to utilize material of better quality than one has to offer. "I did a course in Robotics from Stanford University USA which I followed, just as video" (V3) Web-based 
material may also be a resource for student discussions, and for increasing the creativity of the students, thereby rendering source critique a more relevant competence.

The greatest challenge put forth by the scientists is the matter of what form the interaction should take. "Just watching videos and you can read a book, just as well, right, it's the feedback that's important." (H2) It is a challenge to guarantee the practical level. How should lab-intensive courses be carried out? Can distance supervision function as well as physical meetings? Is meaningful feedback in courses with many participants possible to accomplish? Help is vital when learning how things function. Apart from a wavering motivation for running a course that you might not be paid for, the large hesitation concerns the interaction between students and teachers/supervisors. Notwithstanding, some researchers give examples of well-working distance supervision "Yes, it doesn't take time thanks to recorded lectures" (V3), and others mention automatized functions for interactions. Although automatized multiple choice questions are used in the courses, and automatic structures for communication might be used, there are doubts whether this would function in reality.

\section{Obstacles}

A number of common obstacles are mentioned, but are emphasized differently among the scientists. The commitment of the research groups to the development of open education was not seen as self-evident. Besides the pedagogic challenges mentioned above, various obstacles were observed both at individual research level and at system-level. At a comprehensive level, expanding through increased number of students was problematic due to peak rates already being reached. The number of students is sufficient, and so is the number of applicants. The most common financing system - remuneration per student - was thereby not feasible as the chief alternative. The incentives for increasing the number of students were missing, although some groups expressed a wish to increase the proportion of education in relation to research. They were concerned that specialized courses in the second-cycle education might not attract sufficient number of students, and also hoped for a more long-term, stable funding; the remuneration system was hence deemed better than external financing of research.

Conflicts with the administrative system in terms of admission, curricula, and regulations were apprehended. "Sham postgrads" (students participating in doctoral education, but not formally admitted as doctoral students) in the systems are undesired, but might become more common with more prevalent open second cycle education. How should the matter of validation be resolved? How should we validate our own certificates? How should we validate the certificates of other universities? How can we plan our personnel on demand when we are forced to adjust our personnel resources, and thus require extensive forward planning? The scientists commented that administration systems as well as personnel recruitment are adapted to the current education system, and anticipated that adjusting these would entail many obstacles and problems.

Publishing your own material is problematic, and not only because "Why should somebody watch our lecturer instead of something else?" (H2) but for the risk of it being used in "aberrant" contexts as well. If what a teacher has created is taken apart, perhaps altered and used in another context, he/she might not receive the desired "cred". Several researchers pointed out this risk, and emphasized that traceability should be guaranteed. It should be clearly stated - in the context where the material is used - which university, research group, or scientist that created the material. This would improve the likelihood of one's own investments being visualized, even though the risk under certain circumstances prevails, if the material is wrongly used. Open education was in principal considered a good thing, but it was imperative to actually acquire attention and some form of recognition for the work. 
Matters of copyright were experienced as a vast obstacle, both in terms of the scientist's own material, and material normally used in connection with lectures. Openly publishing your own material is the natural procedure if you are a researcher. You want to spread your material, be cited, and acquire credit for your research. Open distribution may however counteract this. The most important career path is via publications in renowned scientific journals, the number of citations to your articles, and not the amount of research results made accessible in various open forums. The researchers must therefore funnel their work into journals, and be cautious about what research results to publish and where, not to reduce the possibilities of contributions being accepted. To openly publish new data in a course reduces a potential article's newsworthiness and publication value. Existing agreements with publishers on copyrights for research results may also prevent a scientist from using his/her "own" material in an open course. Even though copyright issues were experienced as an obstacle, some scientists still believed that "If I publish openly, I will probably receive more in return". (V2)

The copyright rules were perceived as unclear and difficult to interpret correctly, leading to researchers being worried about handling copyright protected material. The uncertainty, whether someone else's material is permitted to be displayed or cited, increases first and foremost when the teaching context is changed from a classroom, or a "closed" learning management system, into a completely open system. It is hard to discern differences in copyright between using another person's photograph or figure in a classroom and using them in an open course. An example of this is when material is shown and cited in a lecture that is recorded. If this lecture is openly accessible, the "evidence" is available also to people that, following the copyright rules, might claim this to be inappropriate usage. The researchers implied that the so-called teacher exception - a copyright convention for teacher-produced material - necessitates that institutes are managing questions around the course material if a teacher leaves the university. Is it permitted to continue using the course material? What copyright rules apply for campus courses? Is there a difference for open courses? Another detail, complicating copyright issues in open education, is to sort out the rights to use course material collaboratively produced by a production team: "...really difficult, because it is yet another market that need to be addressed" (V1). Another potential obstacle was that scientists having consulting commitments on the side, where they use their own material, might worry about loosing earnings if they make their material openly accessible.

A recurrent opinion expressed by the researchers was that developing open education is time consuming and economically onerous. Normally, course development budgets are inadequate. It would take time to obtain and develop material, and securing the quality would be strenuous. A rather vague obstacle relate to how research groups describe themselves and teachers in collaborative subjects. There are for instance research and educational environments dominated by teachers that hold no interest in technology, and who are conservative in their approach. Teaching on campus was deemed to have higher status than other open and flexible forms of education. Although teachers may not be professed conservative in their pedagogic approach, the matter of education is mostly not prioritized. Instead, research is prioritized; it is creditable, and affects the academic career. The idealism of developing and educating the citizen may exist, but ambitions and commitments are lost in the everyday life. Why develop something that you are not paid for, neither as scientist nor institute? 'It's really hard to change, we have something that works, to some degree at least, on time, so I think it's really needs a push to investigate a way to doing things". (H2) Nevertheless, the scientists believe that developing a more open and flexible education is important. Combining research investment with educational investment "makes perfect sense" (J1). 


\section{Summarizing discussion}

The researchers reckoned that more course material could be published openly than is done today, and that this would support different categories of students. Open education was believed to provide opportunities for increasing the awareness of the scientists' research and education, and for heightening the status of the group. The opportunities available for research groups are dependent on whether you are situated at a high-status university or not, but some scientists believe that also individual research groups might be able to raise their status independently. The views of the researchers are listed in Table 2.

Increased openness also facilitates student recruitment, and increases other researchers' interest in collaboration. Student recruitment was regarded as a complex matter, as it was conceived that status in certain cases was equivalent to the status of the university; and students' choices of where and what to study are founded on many different factors.

Since the development of open courses was considered time consuming and costly, the question arises whether it was understood that animations, simulations, peer projects, etc. could be developed, facilitating a pedagogically altered education, where IT would support the educational process within as well as outside the campus environment. The development of different types of static material that relate to 'knowledge duplication' is after all what appears to be referred to as "publishing" material, etc. The possibility that funded development work would facilitate the handling of copyright issues by the development of new, open, and licensed material was not articulated by the scientists.

The possibilities of open education making a financial profit were considered unresolved. The second cycle courses were so niched that they aimed at few students, but the specialization might at the same time smooth the way for charging course fees. To the scientists, absence of an operating model, including a reinforced recruitment process and options for gaining proceeds, became obstacles for the development of open education.

The researchers in the present study were all part of research groups having established collaborations with industry, and were thereby experienced in managing information that perhaps cannot be made public. Open education was not considered more problematic for the collaboration with companies than campus education.

Table 2: Summary of the results. The rank is merely a broad indicator due to the explorative and qualitative approach of the study and the combination of explicit and implicit statements. The letters exemplifies the different research groups.

\begin{tabular}{|l|}
\hline Organizational purposes \\
\hline Marketing tools to increase international reputation $(\mathrm{H}, \mathrm{J}, \mathrm{M}, \mathrm{V})$ \\
Attract more students to apply $(\mathrm{H}, \mathrm{J}, \mathrm{M}, \mathrm{V})$ \\
Facilitate collaboration with other researchers $(\mathrm{J}, \mathrm{M}, \mathrm{V})$ \\
Facilitate recruitment of new researchers $(\mathrm{J}, \mathrm{M})$ \\
\hline Operating models \\
\hline Open education basically positive $(\mathrm{H}, \mathrm{J}, \mathrm{K}, \mathrm{M}, \mathrm{V})$ \\
Vague models, with unclear purposes and long-sightedness $(\mathrm{H}, \mathrm{J}, \mathrm{K}, \mathrm{M}, \mathrm{V})$ \\
Flexibility enables participation by working persons $(\mathrm{H}, \mathrm{J}, \mathrm{K}, \mathrm{M}, \mathrm{V})$ \\
Free material, but charge for interaction and direct contact with teacher/scientist $(\mathrm{J}, \mathrm{M})$ \\
Charge for examination $(\mathrm{J}, \mathrm{M})$ \\
Paying participants few in niched education $(\mathrm{H})$ \\
Paying participants possible, since the education is niched. $(\mathrm{M})$ \\
\hline
\end{tabular}

European Journal of Open, Distance and e-Learning - Vol. 17 / No. 1 


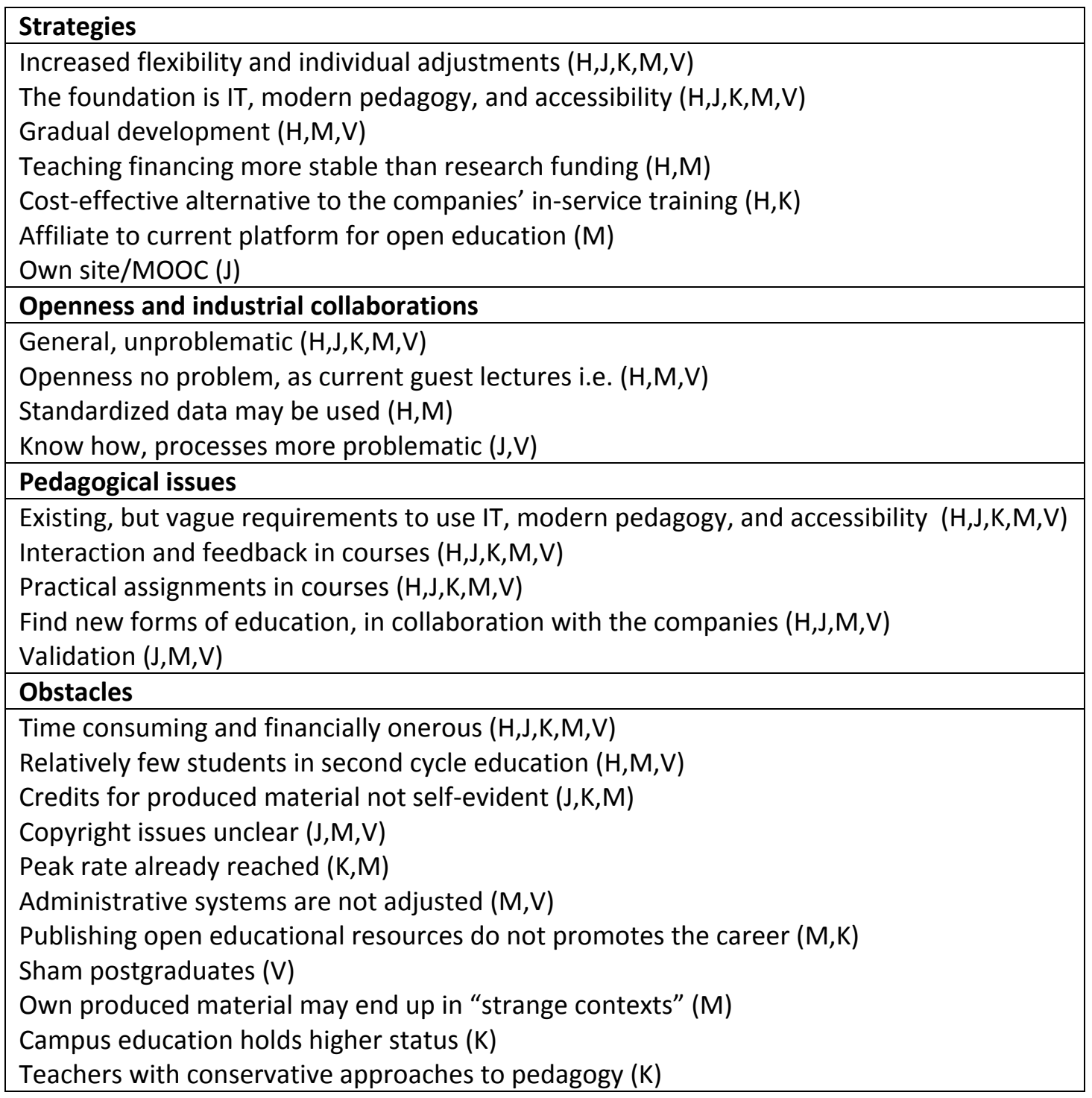

The companies were assessed as being used to interpret what was open, often finding opportunities to market themselves. What can be open in a classroom situation can also be public in an open education. We may assume that the scientists primarily related open education to these traditional lecture or classroom situations, where the lecturer displays and conveys course material and information. If open education had been envisaged as working actively with company processes, simulation with the aid of authentic data and an open network culture, one would probably have foreseen more problems with openness in connection with research collaboration and company data.

The scientists disclosed several plausible paths for the development and marketing of open forms of education. One of these stipulated a gradual development towards increased openness and flexibility, where campus-located education of high quality is of great significance. There would be no need for larger alterations of the organizational or pedagogic structure besides increased technology-enhanced learning. Another path entailed deliberate development work to create MOOCs for the second cycle education. There were also suggestions of joining an existing MOOC-platform, and to launch an open course of their own. Many separate decisions concerning the development work persisted among the research groups that had reached furthest in their planning. The incentives at system- as well as individual level obviously have a great 
impact on how the groups will manage their development; the factors forming the starting points of the incentives were however somewhat ambiguous.

The openness, and the open resources mentioned, often involved lectures to be recorded and made accessible to students. Since second cycle education requires more creativity and independent responsibility than first cycle education, this outlook on development might constitute a problem. A competence network for research and development, comprising research groups as well as industry, should resemble the kind of MOOCs, which Siemens (2012b) deems suitable for creating knowledge, rather than other kinds of MOOCs, which primarily are suitable for conveying information.

An increased demand for applications at Master's level was however recurrently prevalent. All the same, first cycle courses were deemed more relevant than developing large open courses in second cycle education. Furthermore, the MOOCs harboured a number of pedagogic challenges in need of resolution, and few ideas had been produced. Farin (2013) states that an educational process requires a face-to-face-discussion, and cannot be replaced by information transfer in an MOOC. Most of the interviewed scientists construed the studies and possibilities to learn in an MOOC similarly, i.e. interactions in an MOOC are seriously limited. Once again we find that the majority of the researchers are referring to a MOOC with traditional learning and knowledge transmission.

On a personal level, there is a conflict between publishing research results openly and acquiring credits for publishing in renowned scientific journals. Open publishing and being active in social media in order to build networks for collaborations were mentioned, but not seen as a first choice. The research groups seem relatively used to intellectual property agreements (IPRagreements) put in writing prior to collaboration with companies, even though one researcher complained about too much being disclaimed sometimes. The so-called teacher exception is however differently interpreted by different persons, and appears to be a factor of insecurity during the development towards a more open environment.

In spite of these perceptions, some of the scientists displayed an explicit ambition to increase the proportion of open education in collaboration with industry. The statements about open education made by the interviewees can be summarized: As a matter of principle, everything should be open - it is a pronounced trend in society. This seems to be in line with the overall development of private -public partnerships and university-industry links as a key element in the developed industrial countries (Maassen \& Stensaker, 2011). The researchers had however no finalized models for making current or new education open, but rather described fragmentized, organizational purposes, embryonic operating models and strategies, and various obstacles for flexibility and openness. The researchers showed clear ambitions to make education open and accessible for all citizens, but the ambitions and commitments appear to dwindle in the everyday work. Bearing in mind the selection of research groups - groups having applied for funding for development of open courses incorporating technology-enhanced learning - the positive attitude is hardly surprising. What to accomplish, and why this should be accomplished, differed however between the interviewed scientists.

The interest is there, but in order to succeed with research and open second cycle education, the research groups need to calibrate the variables of purposes, operating models, strategies, pedagogic models, and obstacles, and to make them more deliberated. This work could for instance be carried out in collaboration with industry, in order to choose a suitable model for research and development that resembles competence networks and creative MOOCs rather than first cycle education and MOOCs with just a range of video lectures. 


\section{References}

1. Bokor, J. (2012). University of the Future. Ernst \& Young. Available online at http://www.ey.com/Publication/vwLUAssets/University_of_the_future/\$FILE/University _of_the_future_2012.pdf

2. Broman, G. and Östholm, S. (1997). MathCAD in teaching rotor and structural dynamics. In International Journal of Engineering Education, 13(6), (pp. 426-432).

3. Bull, D.D. (2012). From Ripple to Tsunami: The Possible Impact of MOOCs on Higher Education. In DE Quarterly, Spring 12, 2012. Available online at http://eprints.usq.edu.au/22388/1/DEQuarterly_Spring_2012_Edition_No_12.pdf

4. Carroll, M. W. (2013). Creative Commons and the Openness of Open Access. In New England Journal of Medicine, 368(9), (pp. 789-791).

5. Chesler, N.C.; Arastoopour, G.; D’Angelo, C.M.; Bagley, E.A. and Shaffer, D.W. (2013). Design of a Professional Practice Simulator for Educating and Motivating First-Year Engineering Students. In Advances in Engineering Education, 3(1), (pp 1-29). Available online at http://edgaps.org/gaps/wp-content/uploads/aee-vol03-issue03-01.pdf

6. Clarke, T. (2013). The Advance of the MOOCs (Massive Open Online Courses): The Impending Globalisation of Business Education? In Education + Training, 55(4/5), (pp. 403413).

7. Conole, G. (2012). Designing for Learning in an Open World. Springer

8. Daniel. J. (2012). Making Sense of MOOCs: Musings in a Maze of Myth, Paradox and Possibility. Available online at http://sirjohn.ca/wordpress/wpcontent/uploads/2012/08/120925MOOCspaper2.pdf

9. Farin, I. (2013). MOOCS and the future of higher education. In INTED2013 Proceedings, (pp. 5590-5596).

10. Hattie, J. and Marsh, H.W. (2004). One journey to unravel the relationship between research and teaching. In Research and teaching: Closing the divide? An International Colloquium, (pp. 18-19).

11. Hill, P. (2012). Four Barriers that MOOCs must overcome to build a sustainable model. In $e$ Literate. Available online at http://mfeldstein.com/four-barriers-that-moocs-must-overcometo-become-sustainable-model/

12. Karsenti, T. (2013). The MOOC. What the research says. In International Journal of Technologies in Higher Education, 10(2), (pp. 23-37).

13. Kelly, A.P. and Hess, F.M. (2013). Beyond retrofitting: Innovation in higher education. Available online at http://www.hudson.org/files/documents/Beyond\%20RetrofittingInnovation $\% 20$ in $\% 20$ Higher $\% 20 \mathrm{Ed} \% 20 \% 28$ Kelly-Hess, $\% 20 \mathrm{June} \% 202013 \% 29$.pdf

14. Maassen, P. and Stensaker, B. (2011). The knowledge triangle, European higher education policy logics and policy implications. In Higher Education, 61(6), (pp 757-769).

15. Norton, A.; Sonnemann, J. and McGannon, C. (2013). The online evolution: when technology meets tradition in bigher education. Available online at http://grattan.edu.au/static/files/assets/ed9a3429/186_online_higher_education.pdf

16. Rodriguez, O. (2013). The concept of openness behind $\mathrm{c}$ and $\mathrm{x}$-MOOCs (Massive Open Online Courses). In Open Praxis, 5(1), (pp 67-73).

17. Rubin, B. (2013). University Business Models and Online Practices: A Third Way. In Online Journal of Distance Learning Administration, 15(1).

European Journal of Open, Distance and e-Learning - Vol. 17 / No. 1 
18. Siemens, G. (2012a). MOOCs are really a platform. In ELEARNSPACE. Available online at http://www.elearnspace.org/blog/2012/07/25/moocs-are-really-a-platform/

19. Siemens, G. (2012b). What is the theory that underpins our MOOCs? In ELEARNSPACE. Available online at http://www.elearnspace.org/blog/2012/06/03/what-is-the-theory-thatunderpins-our-moocs/

20. Yuan, L. and Powell, S. (2013). MOOCs and Open Education: Implications for Higher Education. JISC CETIS. Available online at http://publications.cetis.ac.uk/2013/667

\section{Acknowledgments}

Collaboration between the Knowledge Foundation (http://www.kks.se) and The Department of Computer and Systems Sciences, Stockholm University (http://www.dsv.su.se) made this study practicable. We are obliged to Stefan Östholm, Olle Vogel and Tony Burden for their comments and help. 